\title{
Metode Pembelajaran Kitab Kuning Di Pondok Pesantren Sunan Drajad Banjarwati Lamongan
}

\author{
Mahfud Ifendi ${ }^{1}$ \\ STAI Sangatta Kutai Timur, Indonesia \\ Email : $\underline{\text { mahfudzifindi@gmail.com }}$
}

\begin{abstract}
Abstrack
The learning method is an important thing that must be considered, in addition to the curriculum content or material to be delivered. Because given the importance of learning methods, an educator must use several methods in the learning process. Both in general or religious subject matter such as the yellow book. The formulation of the problem in this article is to find out how the learning methods in the Sunan Drajad Lamongan Islamic boarding school are. To be able to describe the formulation of the problem, the data collection technique used interviews, observation, and documentation and used data analysis by Milles and Huberman. The results show that in the Sunan Drajad Lamongan Islamic boarding school there are several yellow book learning methods that we often find, including bandongan, sorogan, memorization, deliberation, and collaboration methods. Far from that, in fact, if the use of yellow book learning methods in Islamic boarding schools throughout Indonesia in general and in the Sunan Drajad Lamongan Islamic boarding school, if you can combine some of the above learning methods that we are familiar with, combined with general learning methods such as the role palying method, demonstrations, recitations, field trips, sociodrama and so on will certainly make it easier for students to learn the contents of the yellow book. Why should you combine several methods in a learning process, because one method with another has its own character, advantages and disadvantages
\end{abstract}

Keywords: learning method, yellow book

Abstrak

Metode pembelajaran merupakan hal penting yang harus diperhatikan, selain konten kurikulum atau materi yang akan disampaikan. Karena mengingat pentingnya metode pembelajaran, seorang pendidik harus menggunakan beberapa metode dalam proses pembelajarannya. Baik dalam materi pelajaran umum ataupun keagamaan seperti halnya kitab kuning. Rumusan masalah dalam artikel ini adalah ingin mencari tahu bagaimana metode pembelajaran yang ada di pesantren Sunan Drajad Lamongan. Untuk dapat mendeskripsikan rumusan masalah tersebut maka, teknik pengambilan data menggunakan wawancara, observasi dan dokumentasi serta menggunakan analisis data Milles dan Huberman. Adapun hasilnya menunjukkan bahwa di pesantren Sunan Drajad Lamongan terdapat beberapa metode pembelajaran kitab kuning yang alzim banyak kita temukan, diantaranya adalah metode bandongan, sorogan, hafalan, musyawarah dan kolaborasi. Jauh dari itu sebenarnya jika penggunaan metode-metode pembalajaran kitab kuning di pondok pesantren di seluruh Indonesia pada umumnya dan di pesantren Sunan Drajad Lamongan jika dapat memadukan beberapa metode

${ }^{1}$ Pogram Studi Manajemen Pendidikan Islam Jurusan Tarbiyah, STAI Sangatta Kutai Timur, Kompleks perkantoran Bukit Pelangi, Teluk Lingga, Sangatta Utara, Kutai Timur, Kalimantan Timur. Telp (0811596662) 
pembelajaran di atas yang sudah lazim kita ketahui, dipadukan dengan metode pembelajaran umum seperti metode role palying, demonstrasi, resitasi, karyawisata, sosiodrama dan lain sebagainya tentu akan semakin memudahkan bagi para santri untuk mempelajari isi dari kitab kuning. Mengapa harus memadukan beberapa metode dalam sebuah proses pembelajaran, karena memang satu metode dengan metode lainnya itu memiliki karakter, kelebihan dan kekurangan masing-masing.

Kata kunci: metode pembelajaran, kitab kuning

\section{Pendahuluan}

Banyak karakteristik khas yang nyaris jadi teka- teki, yang susah diformulasikan buat jadi teori. Menaruh sekian banyak rahasia, mempunyai karakteristik yang berbeda yang buatnya jadi salah satunya institusi pendidikan keIslaman yang sukses melahirkan ulama-ulama hebat selama sejarah pertumbuhan Islam di Indonesia. Pembelajaran pesantren dikelola tanpa standar teknis serta manajemen yang baku. Bila terdapat seratus pesantren, berarti pula terdapat seratus wujud, seratus kurikulum, serta seratus-seratus yang lain. Tetapi dalam keragaman yang sangat kaya itu, pesantren mempunyai prinsip yang sama dalam menghelat pembelajaran keagamaan. Seluruh pondok pesantren memegang 3 prinsip pokok, ialah ilmu, amal, serta ikhlas. Tiga pokok yang lain: Iman, Islam, serta Ihsan, ataupun dalam bahasa lain: aqidah, syariah serta akhlak. ${ }^{2}$

Pesantren merupakan sebuah institusi pendidikan Islam yang sudah membuktikan dirinya mampu bertahan dan adaptif dengan semua perubahan. ${ }^{3}$ Hal ini dapat kita lihat bersama bahwa sejak kelahirannya, yakni ketika Islam masuk ke Indonesia dan sampai saat ini eksistensi pesantren tidak pernah padam, kian hari malah kian banyak pesantren yang didirikan. Tentu hal ini dapat kita tarik kesimpulan bahwa pesantren merupakan lembaga pendidikan Islam tertua yang pernah ada di Indonesia. Ada banyak hal menarik yang dapat kita perbincangkan jikalau dihadapkan dengan pesantren, sebuah entitas yang dikenal dengan segala bentuk kesederhanaannya, kemadirian, kebersamaan, rasa persaudaraan yang tinggi, religi dan luhurnya etika atau adab, menjadikan pesantren sebagai topik bahasan yang selalu menarik untuk diperbincangkan sepanjang zaman. ${ }^{4}$

Pondok pesantren identik dengan pembelajaran kitab kuning, yang merupakan salah satu karakteristik yang menarik dari pesantren itu sendiri. ${ }^{5}$ Setidaknya ada lima komponen pokok yang terdapat di dalam pondok pesantren, diantaranya adalah : pondok, sebuah bangunan sebagai tempat tinggal para santri. Masjid, merupakan sentral tempat berlangsungnya proses pembelajaran. Kiai, sebagai tokoh sentral dalam membina, membimbing, dan

${ }^{2}$ Ahmad Achyad, Ismail Qusyairi, and Hadi Ja'far, Mengapa Saya Harus Mondok Di Pesantren (Pasuruan: PT. PUSTAKA SIDOGIRI PONDOK PESANTREN SIDOGIRI, 2009), IX.

${ }^{3}$ Marwan Saridjo, Sejarah Pondok Persantren Di Indonesia (Jakarta: Dharma Bhakti, 1982).

${ }^{4}$ Ali Akbar and Hidayatullah Ismail, "Metode Pembelajaran Kitab Kuning Di Pondok Pesantren Daarun Nahdhah Thawalib Bangkinang," Al-Fikra: Jurnal Ilmiah KeIslaman 17, no. 1 (2018): 21, https://doi.org/10.24014/af.v17i1.5139.

${ }^{5}$ Kompri, Manajemen \& Kepemimpinan Pondok Pesantren, Cetakan ke (Jakarta: Prenadamedia Group, Divisi Kencana, 2018). 
memberi teladan kepada santri. Santri, orang yang belajar di pesantren, yang rela meninggalkan halaman kampung, mengurangi jam bermain dengan teman sebayanya di rumah dan orang yang selalu berharap akan mendapatkan luberan berkah dari sang kiai. Yang terakhir adalah pembelajaran kitab-kitab klasik/kuning (umumnya berwarna kuning, meski saat ini sudah banyak kitabkitab yang memakai kertas warna putih). ${ }^{6}$

Mengkaji kitab kuning, atau kitab-kitab karya ulama salaf menjadi salah satunya icon referensi keilmuan yang sampai sekarang ini masih dilestarikan dengan baik di lingkungan pesantren. Karena hal inilah menjadikan pesantren terkenal dengan keunikan-keunikan yang tidak dapat dijumpai di lembaga pendidikan lainnya.

Pondok Pesantren Sunan Drajad didirikan pada tanggal 7 September 1977 di desa Banjarwati Kecamatan Paciran Kabupaten Lamongan oleh KH. Abdul Ghofur. Menilik dari namanya pondok pesantren ini memang mempunyai ikatan historis, psikologis, dan filosofis yang sangat lekat dengan nama Kanjeng Sunan Drajad, bahkan secara geografis bangunan pondok tepat berada di atas reruntuhan pondok pesantren peninggalan Sunan Drajad yang sempat menghilang dari percaturan dunia Islam di Jawa selama beberapa ratus tahun. Pondok Pesantren Sunan Drajad adalah salah satu pondok pesantren yang memiliki nilai historis yang amat panjang karena keberadaan pesantren ini tak lepas dari nama yang disandangnya, yakni Sunan Drajad. Sunan Drajad adalah julukan dari Raden Qosim putra kedua pasangan Raden Ali Rahmatullah (Sunan Ampel) dengan Nyi Ageng Manila (Putri Adipati Tuban Arya Teja). ${ }^{7}$

Sesuai dengan visi pesantren ini yakni untuk menjadi sebuah pondok pesantren yang mampu melakukan perubahan bagi masyarakat untuk menjadi masyarakat yang madani. Dan meneruskan cita-cita sembilan wali. Serta membentuk insan yang berbudi luhur, berakhlakul karimah, bertaqwa kepada Allah SWT, berpengetahuan luas dan bertanggung jawab terhadap agama, nusa dan bangsa. Tentu untuk mencapai visi tersebut dengan beragam kegiatan yang pada akhirnya adalah terciptanya visi pesantren secara keseluruhan. Di dalam visi pesantren menyebutkan untuk membentuk insan yang berpengetahuan luas, maka dalam hal ini tak lepas kaitanya dengan proses pembelajaran, lebih-lebih untuk mendalami ilmu-ilmu agama yang didapatkan dari mempelajari atau ngaji dengan Kiai dan para ustadz-ustadzah di pesantren.

Dalam artikel ini akan dibahas bagaimana bentuk macam-macam metode pembelajaran kitab kuning yang digunakan dalam pembelajaran setiap harinya di pesantren Sunan Drajad Lamongan, juga di dalamnya dibahas tentang kelebihan dan kekurangan dari masing-masing metode serta bentuk klasifikasi jenis metode pembelajaran kitab kuning di pesantren.

\footnotetext{
${ }^{6}$ Ar Rasikh, "Pembelajaran Kitab Kuning Pada Pondok Pesantren Khusus Al-Halimy Desa Sesela Kabupaten Lombok Barat," Jurnal Penelitian KeIslaman 14, no. 1 (2018): 72.

${ }^{7}$ Agus Sunyoto, Atlas Walisongo, Cetakan IX (Tangerang Selatan: Pustaka IIMaN, 2018), 306.
} 


\section{Hasil dan Pembahasan Metode Pembelajaran}

Metode pembelajaran dapat diartikan sebagai cara yang digunakan untuk mengimplementasikan rencana yang sudah disusun dalam bentuk kegiatan nyata dan praktis untuk mencapai tujuan pembelajaran. ${ }^{8}$ Senada dengan SuDrajad, Afandi dkk menyatakan bahwa metode pembelajaran adalah cara atau tahapan yang digunakan dalam interaksi antara peserta didik dan pendidik untuk mencapai tujuan pembelajaran yang telah ditetapkan sesuai dengan materi dan mekanisme metode pembelajaran. ${ }^{9}$

Metode pembelajaran ialah sesuatu perkakas dalam penerapan pembelajaran, yang digunakan dalam penyampaian modul pelajaran tertentu. Modul pelajaran yang gampang juga kadang-kadang sulit diterima oleh murid, sebab metode ataupun tata cara yang digunakannya kurang pas. Tetapi, kebalikannya pelajaran yang sukar hendak gampang diterima oleh murid, sebab penyampaian serta tata cara yang digunakan gampang dimengerti, pas serta menarik. ${ }^{10}$ Singkatnya kalau dalam proses pendidikan pasti terdapat suatu tujuan yang mau dicapai, buat menggapai tujuan tersebut hingga diguanakanlah wasilah, metode ataupun perantara supaya tujuan pembelajaran bisa tercapai.

\section{Kitab Kuning}

Kitab Kuning ialah salah satu sumber data terpenting dalam kajian Islam. ${ }^{11}$ Tanpa pengetahuan yang mencukupi terhadap sumber ini, sedikit banyaknya pasti berimplikasi kepada kapasitas intelektualitas seseorang pengkaji Islam tersebut. Oleh karenanya, butuh dicoba upaya yang lebih sungguh-sungguh kearah pemasyarakatan kitab ini untuk warga akademis. Tetapi demikian, senantiasa saja ditemui hambatan buat mensosialisasikan Kitab Kuning tersebut. Perihal ini diakibatkan tidak terdapatnya buku yang ada dalam bahasa Indonesia dengan metodologi yang mencukupi buat mempermudah para akademisi tersebut memberdayakan dirinya sanggup membaca Kitab Kuning. ${ }^{12}$

Kitab kuning merupakan sumber ilmu pengetahuan agama yang menjadi warisan yang sangat berharga dai para ulama di masa kejayaan Islam. Pembelajaran kitab kuning merupakan ciri khas dari pondok pesantren, karena memang di pesantrenlah diajarkan berbagai kitab kuning tersebut dan tidak

\footnotetext{
${ }^{8}$ Akhmad SuDrajad, "Pengertian Pendekatan, Strategi, Metode, Teknik, Taktik, Dan Model Pembelajaran," $2003,3$.

${ }_{9}^{9}$ Muhamad Afandi, Evi Chamalah, and Oktarina Puspita Wardani, Model Dan Metode Pembelajaran Di Sekolah, Perpustakaan Nasional Katalog Dalam Terbitan (KDT), vol. 392 (Semarang: UNISSULA PRESS, 2013), 15, https://doi.org/10.1007/s00423-006-0143-4.

10 Siti Maesaroh, "Peranan Metode Pembelajaran Terhadap Minat Dan Prestasi Belajar Pendidikan Agama Islam," Jurnal Kependidikan 1, no. 1 (2013): 155, https://doi.org/10.24090/jk.v1i1.536.

${ }^{11}$ Rasyid Anwar Dalimunthe, Strategi Pembelajaran Kitab Kuning Di Pesantren, ed. Sakholid Nasution

(Medan: Perdana Publishing, 2020).

12 Rasyid Anwar Dalimunthe, 7.
} 
ditemukan di lembaga pendidikan umum, meskipun saat ini ada beberapa sekolah umum yang memakai kitab kuning dalam kurikulumnya. ${ }^{13}$

\section{Metode Pembelajaran Kitab Kuning Di Pesantren Sunan Drajad}

Sebelum kita mendapatkan sebuah pemahaman yang matang dan kompeherensif dari kitab kuning, hal lain yang tak kalah penting adalah bagaimana cara pembelajaran yang kita gunakan atau pakai dalam sebuah proses belajar-mengajar. Ini dilakukan agar apa yang disampaikan dapat berjalan secara efektif dan efisien, supaya apa yang menjadi kebutuhan santri atau siswa dapat terpenuhi dengan baik dan benar.

Banyak sekali metode pembelajaran yang digunakan dalam pembelajaran kitab kuning di pesantren. Seperti yang ada di Pondok Pesantren Sunan Drajad Banjarwati Paciran Lamongan, setidaknya ada lima metode pembelajaran kitab kuning yang diterapkan di sana, antara lain :

\section{Metode Bandongan}

Seperti yang dipaparkan oleh kepala pondok pesantren Sunan Drajad (ust. Moh. Hasan) bahwasanya salah satu metode pembelajaran kitab kuning yang dipakai di pondok ini adalah menggunakan metode bandongan. Dalam metode ini, biasanya seorang kyai atau ustadz membacakan sebuah kitab kuning, menerangkan kata demi kata, kalimat demi kalimat, sedangkan para santri duduk melingkar di hadapan seorang kyai atau ustadz dengan memaknai atau memberikan keterangan pada kitab yang telah mereka bawa masingmasing. Metode pembelajaran ini merupakan salah satu metode klasik yang dipakai dari dahulu bertahan sampai dewasa ini.

Tidak banyak kelebihan dari metode ini dari segi penyampaian materi, karena pembelajaran yang seperti ini terkesan hanya milik kyai, ustadz dan ustadzahnya saja, padahal dalam teori pendidikan proses belajar itu seharusnya tertuju pada siswa (student centered) atau (siswa sebagai subyek pendidikan, bukan sebagai obyek dalam pendidikan) bukan pada ustadz atau gurunya (teacher centered). Senada dengan hal ini, sama seperti yang diungkapkan oleh ustadzah Siti Rahmah bahwa kelebihan metode ini hanya untuk mempertahankan metode para ulama dahulu, alih-alih sambil mencari berkah pada kyai atau ustad/ustadzah yang mengajar para santri (ngalap barokah).

Dalam metode bandongan ini yang menjadi kelebihannya adalah seorang kyai, ustadz/ustadzahnya dapat mengontrol secara langsung proses pembelajarannya. Selain itu, metode ini cocok jika materi yang disampaikan begitu luas namun waktunya sedikit. Sehingga penggunaan metode pembelajaran kitab kuning model bandongan ini akan pas jika dalam kondisi di atas, dan akan kurang pas jika dalam kondisi sebaliknya. Di semua pesantren salaf, mayoritas masih mempertahankan metode pembelajaran kitab kuning yang demikian ini. Hal ini sama apa yang terdapat di Pondok Pesantren

${ }^{13}$ Tamsir and Warisuddin Soleh, "PEMBELAJARAN KITAB KUNING DI PONDOK PESANTREN (Studi Kasus Di Pondok Pesantren As'ad Olak Kemang Kota Jambi)," Jurnal Mikraf: Jurnal Pendidikan 1, no. 2 (2020): 42. 
Tarbiyah Islamiyah Malalo ${ }^{14}$, Pesantren Islam Internasional Terpadu Asy-Syifaa Wal Mahmuudiyyah ${ }^{15}$, Pesantren Nurul Hidayah ${ }^{16}$, pesantren khusus al-Halimy desa Sesela kabupaten Lombok Barat ${ }^{17}$, pesantren al-Mahalli Brajan Wonokromo Pleret Bantul ${ }^{18}$, Pesantren Roudlotul Muta'allimin Wonosalam Wanar-PucukLamongan $^{19}$, pesantren cilik al-Amien (PONCILA) Tegal Prenduan ${ }^{20}$, Pesantren As'ad Olak Kemang Kota Jambi ${ }^{21}$, Pesantren Nurul Qur'an Pakunden Ponorogo ${ }^{22}$ , pesantren Luhur Malang23, Pesantren Daarun Nahdhah Thawalib Bangkinang ${ }^{24}$, Pesantren Syekh Arsyad Albanjary, dan Pondok Pesantren Salafiyah Subulussalam Balikpapan ${ }^{25}$, Pesantren Attarbiyah Guluk-Guluk ${ }^{26}$, serta pesantren tradisional di pesantren Buntet ${ }^{27}$, yang masih menggunakan metode pembelajaran kitab kuning berupa metode bandongan.

\section{Metode Sorogan}

Metode pembelajaran kitab kuning lainnya yang terdapat di pesantren Sunan Drajad adalah metode sorogan. Yakni setiap santri membacakan kitab kuning di hadapan ustadz/ustadzahnya, kemudian ustadz/uztadzah menyimak dan mengevaluasi bacaan santri. ${ }^{28}$ Menurut Ustadz Siswandi (Kepala Madrasah

${ }^{14}$ Rosma Eka Putri, "Pelaksanaan Metode Pembelajaran Kitab Kuning Di Pondok Pesantren Tarbiyah Islamiyah Malalo," El-Hekam 5, no. 2 (2020): 189, https://doi.org/10.31958/jeh.v5i2.2661.

${ }^{15}$ Heri Khoiruddin and Rizki Ikhwan Ferisal, "Manajemen Pembelajaran Kitab Kuning Di Pondok Pesantren," Jurnal Isema: Islamic Educational Management 3, no. 1 (2018): 15-27, https://doi.org/10.15575/isema.v3i1.3279.

${ }_{16}$ Mochammad Mu'izzuddin, Juhji Juhji, and Hasbullah Hasbullah, "Implementasi Metode Sorogan Dan Bandungan Dalam Meningkatkan Kemampuan Membaca Kitab Kuning," Geneologi PAI: Jurnal Pendidikan Agama Islam 6, no. 1 (2019): 43, https://doi.org/10.32678/geneologipai.v6i1.1942.

${ }^{17}$ Rasikh, "Pembelajaran Kitab Kuning Pada Pondok Pesantren Khusus Al-Halimy Desa Sesela Kabupaten Lombok Barat."

${ }^{18}$ Azuma Fela Sufa, "Efektifitas Metode Pembelajaran Kitab Kuning Di Madrasah Diniyah Pondok Pesantren AlMahalli Brajan Wonokromo Pleret Bantul Tahun Ajaran 2013/2014," LITERASI (Jurnal Ilmu Pendidikan) 5, no. 2 (2017): 169, https://doi.org/10.21927/literasi.2014.5(2).169-186.

${ }^{19}$ Mokhamad Ali Musyaffa, "DESAIN PEMBELAJARAN KITAB KUNING DI SMP TERBUKA PONDOK PESANTREN ROUDLOTUL MUTA ' ALLIMIN," n.d., 1-14.

${ }^{20}$ A Washil and Firdausi, "Analisis Terhadap Kurikulum Pembelajaran Kitab Kuning Di Pondok Pesantren Cilik AL-Amien (PONCILA) Tegal Prenduan," Jurnal Pemikiran Dan Ilmu Keislaman 2, no. 2 (2019): 410-27.

${ }^{21}$ Tamsir and Soleh, "PEMBELAJARAN KITAB KUNING DI PONDOK PESANTREN (Studi Kasus Di Pondok Pesantren As'ad Olak Kemang Kota Jambi)."

22 Yuli Umro'atin, "POLA PEMBELAJARAN KITAB KUNING: Studi Kasus Di Madrasah Salafiyah Pondok Pesantren Nurul Qur'an Pakunden Ponorogo," NGABARI: Jurnal Studi Islam Dan Sosial 10, no. 02 (2017): 67-82.

${ }^{23}$ M. Faridl Darmawan2 M.Syafiuddin Shobirin1*, "Pengembangan Pembelajaran Kitab Kuning Di Pesantren Luhur Malang M.Syafiuddin," Journal of Educatio and Management Studies 2, no. 1 (2019): 15-24.

${ }^{24}$ Akbar and Ismail, "Metode Pembelajaran Kitab Kuning Di Pondok Pesantren Daarun Nahdhah Thawalib Bangkinang."

${ }^{25}$ Abu Muslim, "Refleksi Pembelajaran Kitab Kuning Pada Pondok Pesantren Di Balikpapan," PUSAKA : Jurnal Khazanah Keagamaan 6, no. 1 (2018): 45-60.

${ }^{26}$ Effendi Chairi, "Pengembangan Metode Bandongan Dalam Kajian Kitab Kuning Di Pesantren Attarbiyah Guluk-Guluk Dalam Perspektif Muhammad Abid Al-Jabiri," Nidhomul Haq : Jurnal Manajemen Pendidikan Islam 4, no. 1 (2019): 70-89, https://doi.org/10.31538/ndh.v4i1.233.

${ }^{27}$ Moh. Khuailid, "Sistem Pendidikan Pesantren Tradisional Di Pesantren Buntet Pada Masa Kepemimpinan Kh. Abdullah Abbas," Tsaqafatuna: Jurnal Ilmu Pendidikan Islam 1, no. 1 (2018): 42-59, https://jurnal.stitbuntetpesantren.ac.id/index.php/tsaqafatuna/article/view/10.

${ }^{28}$ Yuli Umro'atin, "POLA PEMBELAJARAN KITAB KUNING: Studi Kasus Di Madrasah Salafiyah Pondok Pesantren Nurul Qur'an Pakunden Ponorogo." 
Diniyah Sunan Drajad), sistem ini baik untuk santri dalam hal membaca kitab kuning, karena santri dituntut untuk belajar sebelumnya sebelum disuruh maju satu per satu oleh seorang ustadz/ustadzahnya di saat proses belajar-mengajar berlangsung. Oleh karena itu pemahaman santri lebih matang karena sejak awal sudah muthola'ah.

Apa yang disampaikan oleh ustadz Siswandi adalah benar adanya bahwa metode yang memberikan waktu seluas-luasnya kepada santri (peserta didik) merupakan metode yang dianggap efektif dalam mempelajari suatu materi. Dalam hal ini yang aktif atau dominan dalam proses pembelajaran adalah seorang santri (peserta didik), bukan kyai, ustadz/ustadzah (guru) nya. Pembelajaran yang model student centered inilah yang dewasa ini digalakkan dengan tujuan memberikan ruang dan waktu sebebas mungkin kepada peserta didik untuk mengekpresikan kemampuannya dalam belajar. Dengan menggunakan metode ini, seorang guru dapat memantau dan mengevaluasi secara langsung kemampuan para santri dan tentunya metode ini akan sangat membantu para santri untuk belajar memahami apa yang terdapat dalam kitab kuning yang tengah dipelajari.

Metode pembelajaran kitab kuning di pondok pesantren Sunan Drajad Lamongan ini, khususnya metode sorogan telah sesuai atau senada dengan hasil penelitian Nurul Hidayati M yang menyatakan bahwa metode sorogan sangat efektif untuk meningkatkan pemahaman para santri dalam memahami makna yang ada di dalam kitab. ${ }^{29}$ Hasil penelitian lain juga memperkuat bahwa metode pembelajaran sorogan ini memiliki efektivitas dan signifikansi yang tinggi dalam mencapai hasil belajar. ${ }^{30}$ Metode pembelajaran kitab kuning yang sorogan ini sebenarnya dilihat dari perkembangan jenis metode pembelajaran, sebenarnya termasuk jenis perkembangan metode yang modern. Kenapa demikian karena dalam prakteknya, metode pembelajaran sorogan ini terjalin interaksi yang inten antara santri dan kyai/ustadz. Sehingga bisa dikatakan ini merupakan salah satu bentuk dari perkembangan penggunaan metode pembelajaran kitab kuning. ${ }^{31}$

\section{Metode Musyawarah}

Metode pembelajaran kitab kuning berikutnya adalah musyawarah. Metode ini biasanya menjadi salah satu pemandangan menarik di setiap waktu kalau kita lihat hampir di semua pesantren tak terkecuali di pesantren Sunan Drajad. Biasanya mereka membuat halaqoh atau kelompok mungkin jumlahnya sampai dua puluhan atau bahkan dalam jumlah yang lebih besar lagi. Dalam pelaksanaannya, metode ini ada dua atau tiga santri yang maju membaca, menerangkan dan menampung beberapa pertanyaan yang akan disampaikan dari santri lainnya. Dua orang ini tadi terdiri dari qori' (pembaca kitab) dan

\footnotetext{
${ }^{29}$ Nurul Hidayati Murtafiah, "Efektivitas Penerapan Metode Sorogan Kitab Al Jurumiyah Dalam Meningkatkan Kemampuan Membaca Kitab Kuning," An Nida 1, no. 1 (2021): 24.

${ }^{30}$ Akbar and Ismail, "Metode Pembelajaran Kitab Kuning Di Pondok Pesantren Daarun Nahdhah Thawalib Bangkinang," 30.

${ }^{31}$ Muhammad Thoriqussu 'ud, "Model-Model Pengembangan Kajian Kitab Kuning Di Pondok Pesantren," AtTajdid: Jurnal Ilmu Tarbiyah 1, no. 2 (2012): 236, http://ejournal.stitmuhpacitan.ac.id/index.php/attajdid/article/view/13.
} 
seorang moderator yang mengatur jalannya musyawarah tadi. Di sisi lain tentunya ada seorang pembimbing yang mengarahkan para santri tentang tema yang dibahas pada saat itu. Di pesantren Sunan Drajad, seperti yang diungkapkan oleh akhi Faishal bahwasanya metode musyawarah ini banyak sekali manfaat yang dapat diambil, antara lain yakni dengan menggunakan metode ini dapat dijadikan sebagai wahana untuk menimbulkan dan meningkatkan rasa percaya diri dalam jiwa santri karena mereka belajar menerangkan layaknya seorang guru dan dari sistem semacam ini banyak sekali masukan-masukan atau pendapat yang saling melengkapi satu sama lain.

Di beberapa pesantren di Indonesia memang kental akan metode kitab kuning dengan cara musyawarah/diskusi/mudzakarah. Apapun istilahnya itu, yang jelas metode ini marak dipakai di banyak pesantren ${ }^{32}$, tak terkecuali sebagaimana yang ada di madrasah diniyah pondok pesantren al-Mahalli Brajan Wonokromo Pleret Bantul ${ }^{33}$, SMP Terbuka Pondok Pesantren Roudlotul Muta'allimin Wonosalam Wanar-Pucuk-Lamongan ${ }^{34}$, Pondok Pesantren Manbaul Hikam, Desa Putat, Kecamatan Tanggulangin Sidoarjo ${ }^{35}$, dan masih banyak lagi yang lainnya.

Metode musyawarah ini juga dapat dikatakan sebagai salah satu upaya untuk meningkatan kemampuan membaca kitab kuning santri sebagaimana yang terdapat pada Pondok Pesantren Al-Ishlah Bandar Kidul Kediri. ${ }^{36}$

\section{Metode Hafalan}

Seperti yang disampaikan oleh ustadz M. Mas'ud (kepala madrasah mu'alimin dan mu'alimat Sunan Drajad) bahwa di pondok pesantren Sunan Drajad, metode hafalan ini biasanya diterapkan pada kitab-kitab tertentu yang secara wajib harus dihafalkan oleh santri. Di lembaga pendidikan mu'alimin dan mu'alimat, sistem ini digunakan untuk menghafal sya'ir atau nadzom yang berhubungan dengan ilmu nahwu dan shorof. Untuk kelas 1-2, harus menghafalkan nadzom-nadzom Imrithy, dan untuk kelas 3-6 mereka harus menghafalkan nadzom Alfiyah Ibnu Malik. ${ }^{37} \mathrm{Hal}$ ini sama dengan apa yang terjadi di pesantren pada umumnya di seluruh pelosok negeri, yang tidak meninggalkan metode hafalan sebagai upaya untuk mempelajari teks-teks pendek (bait/nadzom). ${ }^{38}$

\footnotetext{
32 Thoriqussu 'ud, 236.

${ }^{33}$ Sufa, "Efektifitas Metode Pembelajaran Kitab Kuning Di Madrasah Diniyah Pondok Pesantren AlMahalli Brajan Wonokromo Pleret Bantul Tahun Ajaran 2013/2014," 169.

${ }^{34}$ Musyaffa, “DESAIN PEMBELAJARAN KITAB KUNING DI SMP TERBUKA PONDOK PESANTREN ROUDLOTUL MUTA' ALLIMIN," 7.

${ }_{35}$ Rani Rakhmawati, "Syawir Pesantren Sebagai Metode Pembelajaran Kitab Kuning Di Pondok Pesantren Manbaul Hikam Desa Putat, Kecamatan Tanggulangin, Kabupaten Sidoarjo- Jawa Timur," AntroUnairdotNet V, no. 2 (2016): 349, http://journal.unair.ac.id.

${ }^{36}$ Moh. Tasi'ul Jabbar, Wahidul Anam, Anis Humaidi, “Upaya Kiai Dalam Meningkatkan Kemampuan Membaca Kitab Kuning," Edudeena 1, no. 1 (2017): 50, https://doi.org/10.30762/ed.v1i1.446.

${ }^{37}$ Hasil wawancara peneliti dengan Ustadz M. Mas'ud

${ }^{38}$ Bahrudin and Moh Rifa'i, "Implementasi Pembelajaran Kitab Kuning Sebagai Upaya Pembentukan Karakter Religius Santri," TA'LIM : Jurnal Studi Pendidikan Islam 4, no. 1 (2021): 16.
} 


\section{Metode Kolaborasi}

Dari sekian banyak sistem pembelajaran kitab kuning yang ada di pesantren Sunan Drajad, ternyata ada sebuah upaya untuk mengkolaborasikan dua metode pembelajaran kitab kuning menjadi satu metode yakni menggabungkan antara bandongan dan sorogan. Dalam metode ini, mula-mula seorang ustadz membacakan kitab dan menerangkan kepada santri kemudian ustadz tersebut menyuruh para santri untuk bermusyawarah tentang pokok pembahasan yang sedang diajarkannya. Metode ini cukup efektif bagi santri karena mereka mendapatkan banyak pemahaman atau pengetahuan dari ustadz dan teman-temanya secara langsung dan diakhir sebelum pembelajaran selesai, seorang ustadz biasanya mengevaluasi (menyuruh membaca kitabnya) satu per satu atau sebagian santri tentang materi yang diajarkan. ${ }^{39}$ Bahkan santri lain menambahi pendapatnya akhi Faishal tadi, yakni metode ini akan berjalan lebih maksimal lagi andaikan apa yang sudah didapatkan tadi dihafalkan oleh tiaptiap santri. Jadi kesimpulannya menggabungkan tiga metode pembelajaran sekaligus, yaitu bandongan, sorogan dan hafalan.

Penggabungan metode pembelajaran baik yang bersifat klasik seperti bandongan, sorogan, hafalan dan musyawarah, jika digabungkan dengan metode-metode pembelajaran modern umumnya seperti metode demonstrasi, karya wisata, resitasi, role playing dan lain-lain tentu akan menambah ketertarikan dan memudahkan para santri yang belajar di pesantren. Hal ini sama dengan apa yang dirumuskan oleh Rusdi terkait dengan Pengembangan Metode Pembelajaran Kitab Kuning dalam Mencetak Ahli Fiqh. ${ }^{40}$ Dengan beragamnya metode pembelajaran kitab kuning yang digunakan, maka besar harapan pemahaman dan pengetahuan para santri dalam memahami dan mempelajari isi kitab kuning dapat bertahan lama, masuk ke dalam hati sanubari dan akan diimplementasikan dalam kehidupan mereka sehari-hari, baik ketika masih di pesantren maupun ketika kelak mereka akan pulang ke rumah masingmasing.

Tentu dalam pelaksanaannya banyak kendala dalam menyampaikan materi yang ada pada kitab kuning dengan menggunakan metode pembelajaran yang sudah. Hal ini seperti yang disampaikan oleh salah satu guru Pondok Pesantren As'ad Olak Kemang Kota Jambi menyatakan bahwa sulitnya mencari metode pembelajarn kitab kuning yang cocok bagi santri karena memang mereka memiliki latar belakang pendidikan dan gaya belajar yang berbeda-beda. ${ }^{41}$ Oleh karena itu apa yang sedang diupayakan oleh santri-santri yang sedang belajar di pondok pesantren Sunan Drajad ini bisa menjadi referensi bahwa dalam belajar kitab kuning tidak cukup jika hanya menggunakan satu jenis metode pembelajaran. Harus butuh metode lainnya untuk mendukung kinerja dari metode yang dipakai. Inilah yang kemudian disebut dengan metode kolaborasi,

${ }^{39}$ Hasil wawancara peneliti dengan Akhi Faishal (Pengurus Harian Ma'had 'Aly)

${ }^{40}$ Rusdi, "Pengembangan Metode Pembelajaran Kitab Kuning Dalam Mencetak Ahli Figh," An-Nuha 5, no. 1 (2018): 63 .

${ }^{41}$ Tamsir and Soleh, "PEMBELAJARAN KITAB KUNING DI PONDOK PESANTREN (Studi Kasus Di Pondok Pesantren As'ad Olak Kemang Kota Jambi)," 50. 
memadukan beberapa metode pembelajaran guna menopang atau menunjang pemahaman para santri dalam mem[elajari kitab kuning.

\section{Kelebihan dan kekurangan Metode Pembelajaran Kitab Kuning}

\begin{tabular}{|c|c|c|}
\hline Metode & Ketebihn & Ketematran \\
\hline Bandongan & $\begin{array}{l}\text { Santri dapat bertanya langsung } \\
\text { kepada kyai/ustadz secara } \\
\text { langsung, menjangkau massa yang } \\
\text { banyak dalam waktu singkat, } \\
\text { kyai/ustadz/ustadzah aktif. }\end{array}$ & $\begin{array}{l}\text { Santri pasif, sukar mengevaluasi } \\
\text { kemampuan santri. }\end{array}$ \\
\hline Sorogan & $\begin{array}{l}\text { Mudah mengevaluasi kemampuan } \\
\text { santri, dapat meningkatkan } \\
\text { pemahaman santri, persiapan lebih } \\
\text { banyak. }\end{array}$ & $\begin{array}{l}\text { Memakan waktu yang banyak, } \\
\text { santri yang belum maju ke hadapan } \\
\text { ustadz/ustadzahnya berpotensi } \\
\text { ramai/gaduh, grogi dalam } \\
\text { menyampaikan }\end{array}$ \\
\hline Musyawarah & $\begin{array}{l}\text { Pemahaman lebih komprehensif, } \\
\text { saling bersaing dalam keaktifan, } \\
\text { melatih mental. }\end{array}$ & $\begin{array}{l}\text { Umumnya, yang aktif semakin aktif } \\
\text { begitu juga sebaliknya, berpotensi } \\
\text { gaduh jika tidak ada pembimbing, } \\
\text { grogi dalam presentasi }\end{array}$ \\
\hline Hafalan & $\begin{array}{l}\text { Dapat dijadikan modal/pedoman } \\
\text { dasar untuk membaca kitab kuning, } \\
\text { Untuk memperkuat pemahaman } \\
\text { santri dalam memahami kitab } \\
\text { kuning, Dapat menghafal semua } \\
\text { materi }\end{array}$ & $\begin{array}{l}\text { Kadang-kadang jadwal hafalan } \\
\text { benturan dengan kegiatan lain, } \\
\text { biasanya santri malas dalam hal } \\
\text { hafalan karena terlalu menuntut }\end{array}$ \\
\hline Kolaborasi & $\begin{array}{l}\text { Santri lebih banyak menguasai } \\
\text { materi kitab kuning karena sudah } \\
\text { ada persiapan, ilmu dan } \\
\text { Pemahaman lebih komplek } \\
\text { didapatkan }\end{array}$ & $\begin{array}{l}\text { Belum diimplementasikan secara } \\
\text { penuh, waktu pelaksanaannya } \\
\text { terlalu malam }\end{array}$ \\
\hline
\end{tabular}

Tabel 1. Kelebihan dan kekurangan metode pembelajaran kitab kuning

\section{Klasifikasi Metode Pembelajaran Kitab Kuning Di Pesantren}

Dilihat dari jenis pengelompokaannya, maka metode pembelajaran kitab kuning pada umunya yang ada di pondok pesantren dapat dijelaskan dalam tabel di bawah ini ${ }^{42}$ :

\begin{tabular}{cc}
\hline Ketote & Kelompok \\
\hline Bandongan & Individu \\
Sorogan & Kelompok \\
Musyawarah & Individu \\
Hafalan & Kelompok \\
Kolaborasi &
\end{tabular}

Tabel 2. Klasifikasi metode pembelajaran kitab kuning

Metode pembelajaran kitab kuning yang berupa bandongan merupakan metode pembelajaran yang bersifat kelompok. Karena memang dalam prakteknya metode pembelajaran ini dilakukan secara berkelompok atau dalam bentuk halaqoh. Sama halnya dengan metode bandongan, metode pembelajaran

${ }^{42}$ Tamsir and Soleh, 48. 
kitab kuning berupa musyawarah dan kolaborasi juga sama. Artinya ketiga metode pembelajaran ini secara praktek pelaksanaannya dilakukan dengan cara berkelompok atau berjamaah. Sedangkan metode pembelajaran kitab kuning yang berupa sorogan dan hafalan merupakan metode pembelajaran yang bersifat individual. Baik metode pembelajaran yang berorientasi pada kelompok ataupun individual, jika diakomodir dengan mengkolaborasikan dengan berbagai macam metode pembelajaran kitab kuning lainnya dan metode pembelajaran pada umumnya, kemungkinan besar hal ini akan semakin menambah kemudahan bagi santri dalam belajar kitab kuning di pesantren dan merupakan salah satu bentuk usaha nyata perhatian kita dalam menjaga dan merawat tradisi yang ada di nusantara, khususnya dalam lingkup pesantren.

\section{Kesimpulan}

Metode pembelajaran merupakan hal penting yang harus diperhatikan, selain konten kurikulum atau materi yang akan disampaikan. Karena mengingat pentingnya metode pembelajaran, seorang pendidikan harus menggunakan beberapa metode dalam setiap proses pembelajarannya. Baik dalam materi pelajaran umum ataupun keagamaan seperti kitab kuning. Ada beberapa metode pembelajaran kitab kuning yang lazim digunakan, diantaranya adalah bandongan, sorogan, hafalan, dan musyawarah. Jauh dari itu sebenarnya jika penggunaan metode-metode pembalajaran kitab kuning di pondok pesantren di seluruh Indonesia pada umumnya dan di pondok pesantren Sunan Drajad Lamongan jika dapat memadukan beberapa metode pembelajaran di atas yang sudah lazim kita ketahui dengan metode pembelajaran umum seperti metode role palying, demonstrasi, resitasi, karyawisata, sosiodrama dan lain sebagainya tentu akan semakin menambah kemudahan bagi para santri untuk mempelajari isi dari kitab kuning.

\section{Daftar pustaka}

Afandi, Muhamad, Evi Chamalah, and Oktarina Puspita Wardani. Model Dan Metode Pembelajaran Di Sekolah. Perpustakaan Nasional Katalog Dalam Terbitan (KDT). Vol. 392. Semarang: UNISSULA PRESS, 2013. https://doi.org/10.1007/s00423-006-0143-4.

Ahmad Achyad, Ismail Qusyairi, and Hadi Ja'far. Mengapa Saya Harus Mondok Di

Pesantren. Pasuruan: PT. PUSTAKA SIDOGIRI PONDOK PESANTREN SIDOGIRI, 2009.

Akbar, Ali, and Hidayatullah Ismail. "Metode Pembelajaran Kitab Kuning Di Pondok Pesantren Daarun Nahdhah Thawalib Bangkinang." Al-Fikra: Jurnal Ilmiah Keislaman 17, no. 1 (2018): 21. https://doi.org/10.24014/af.v17i1.5139. 
Bahrudin, and Moh Rifa'i. “Implementasi Pembelajaran Kitab Kuning Sebagai Upaya Pembentukan Karakter Religius Santri." TA'LIM: Jurnal Studi Pendidikan Islam 4, no. 1 (2021): 1-21.

Chairi, Effendi. “Pengembangan Metode Bandongan Dalam Kajian Kitab Kuning Di Pesantren Attarbiyah Guluk-Guluk Dalam Perspektif Muhammad Abid Al-Jabiri." Nidhomul Haq : Jurnal Manajemen Pendidikan Islam 4, no. 1 (2019): 70-89. https://doi.org/10.31538/ndh.v4i1.233.

Fuadah, Fitriyah Samrotul, and Hary Priatna Sanusi. "MANAJEMEN PEMBELAJARAN DI PONDOK PESANTREN.” JURNAL ISEMA:Islamic Educational Management 02, no. $02 \quad$ (2017): 59-65. http://dx.doi.org/10.1016/j.encep.2012.03.001.

Khoiruddin, Heri, and Rizki Ikhwan Ferisal. "Manajemen Pembelajaran Kitab Kuning Di Pondok Pesantren." Jurnal Isema: Islamic Educational Management 3, no. 1 (2018): 15-27. https://doi.org/10.15575/isema.v3i1.3279.

Khuailid, Moh. "Sistem Pendidikan Pesantren Tradisional Di Pesantren Buntet Pada Masa Kepemimpinan Kh. Abdullah Abbas." Tsaqafatuna: Jurnal Ilmu Pendidikan Islam 1, no. 1 (2018): 42-59. https://jurnal.stitbuntetpesantren.ac.id/index.php/tsaqafatuna/article/view/10.

Kompri. Manajemen \& Kepemimpinan Pondok Pesantren. Cetakan ke. Jakarta: Prenadamedia Group, Divisi Kencana, 2018.

M.Syafiuddin Shobirin1*, M. Faridl Darmawan2. "Pengembangan Pembelajaran Kitab Kuning Di Pesantren Luhur Malang M.Syafiuddin." Journal of Educatio and Management Studies 2, no. 1 (2019): 15-24.

Maesaroh, Siti. “Peranan Metode Pembelajaran Terhadap Minat Dan Prestasi Belajar Pendidikan Agama Islam." Jurnal Kependidikan 1, no. 1 (2013): 150-68. https://doi.org/10.24090/jk.v1i1.536.

Mu'izzuddin, Mochammad, Juhji Juhji, and Hasbullah Hasbullah. "Implementasi

Metode Sorogan Dan Bandungan Dalam Meningkatkan Kemampuan Membaca Kitab Kuning." Geneologi PAI: Jurnal Pendidikan Agama Islam 6, no. 1 (2019): 43. https://doi.org/10.32678/geneologipai.v6i1.1942. 
Murtafiah, Nurul Hidayati. “Efektivitas Penerapan Metode Sorogan Kitab Al Jurumiyah Dalam Meningkatkan Kemampuan Membaca Kitab Kuning." An Nida 1, no. 1 (2021): 18-25.

Muslim, Abu. “Refleksi Pembelajaran Kitab Kuning Pada Pondok Pesantren Di Balikpapan." PUSAKA : Jurnal Khazanah Keagamaan 6, no. 1 (2018): 45-60.

Musyaffa, Mokhamad Ali. “DESAIN PEMBELAJARAN KITAB KUNING DI SMP TERBUKA PONDOK PESANTREN ROUDLOTUL MUTA ' ALLIMIN," n.d., 1-14.

Putri, Rosma Eka. “Pelaksanaan Metode Pembelajaran Kitab Kuning Di Pondok Pesantren Tarbiyah Islamiyah Malalo." El -Hekam 5, no. 2 (2020): 189. https://doi.org/10.31958/jeh.v5i2.2661.

Rakhmawati, Rani. "Syawir Pesantren Sebagai Metode Pembelajaran Kitab Kuning Di Pondok Pesantren Manbaul Hikam Desa Putat, Kecamatan Tanggulangin , Kabupaten Sidoarjo- Jawa Timur." AntroUnairdotNet V, no. 2 (2016): 349-60. http://journal.unair.ac.id.

Rasikh, Ar. “Pembelajaran Kitab Kuning Pada Pondok Pesantren Khusus AlHalimy Desa Sesela Kabupaten Lombok Barat." Jurnal Penelitian Keislaman 14, no. 1 (2018): 71-84.

Rasyid Anwar Dalimunthe. Strategi Pembelajaran Kitab Kuning Di Pesantren. Edited by Sakholid Nasution. Medan: Perdana Publishing, 2020.

Rusdi. "Pengembangan Metode Pembelajaran Kitab Kuning Dalam Mencetak Ahli Fiqh." An-Nuha 5, no. 1 (2018): 3-56.

Saridjo, Marwan. Sejarah Pondok Persantren Di Indonesia. Jakarta: Dharma Bhakti, 1982.

Sudrajat, Akhmad. "Pengertian Pendekatan, Strategi, Metode, Teknik, Taktik, Dan Model Pembelajaran," 2003.

Sufa, Azuma Fela. “Efektifitas Metode Pembelajaran Kitab Kuning Di Madrasah Diniyah Pondok Pesantren Al-Mahalli Brajan Wonokromo Pleret Bantul Tahun Ajaran 2013/2014." LITERASI (Jurnal Ilmu Pendidikan) 5, no. 2 (2017): 169. https://doi.org/10.21927/literasi.2014.5(2).169-186. 
Sunyoto, Agus. Atlas Walisongo. Cetakan IX. Tangerang Selatan: Pustaka IlMaN, 2018.

Tamsir, and Warisuddin Soleh. "PEMBELAJARAN KITAB KUNING DI PONDOK PESANTREN (Studi Kasus Di Pondok Pesantren As'ad Olak Kemang Kota Jambi)." Jurnal Mikraf: Jurnal Pendidikan 1, no. 2 (2020): 42-54.

Thoriqussu 'ud, Muhammad. "Model-Model Pengembangan Kajian Kitab Kuning Di Pondok Pesantren." At-Tajdid: Jurnal Ilmu Tarbiyah 1, no. 2 (2012): $225-39$.

http://ejournal.stitmuhpacitan.ac.id/index.php/attajdid/article/view/13.

Wahidul Anam, Anis Humaidi, Moh. Tasi'ul Jabbar,. “Upaya Kiai Dalam Meningkatkan Kemampuan Membaca Kitab Kuning." Edudeena 1, no. 1 (2017): 43-52. https://doi.org/10.30762/ed.v1i1.446.

Washil, A, and Firdausi. "Analisis Terhadap Kurikulum Pembelajaran Kitab Kuning Di Pondok Pesantren Cilik AL-Amien (PONCILA) Tegal Prenduan." Jurnal Pemikiran Dan Ilmu Keislaman 2, no. 2 (2019): 410-27.

Yuli Umro'atin. "POLA PEMBELAJARAN KITAB KUNING: Studi Kasus Di Madrasah Salafiyah Pondok Pesantren Nurul Qur'an Pakunden Ponorogo." NGABARI : Jurnal Studi Islam Dan Sosial 10, no. 02 (2017): 67-82. 